\title{
Properties of Thermobifida fusca Peroxidase Tfu-1649 and its Combined Synergistic Effects with Xylanase on Lignocellulose Degradation
}

\author{
Wan-Yu Liao, ${ }^{\mathrm{a}}$ Yu-Chun Huang, ${ }^{\mathrm{a}, \mathrm{b}}$ Wei-Lin Chen, ${ }^{\mathrm{a}, \mathrm{b}}$ Cheng-Yu Chen, ${ }^{\mathrm{c}}$ and \\ Chao-Hsun Yang a,b,*
}

\begin{abstract}
Lignocelluloses are comprised of cellulose, hemicellulose, and lignins, which constitute plant biomass. Since peroxidases can degrade lignins, the authors examined peroxidase Tfu-1649, which is secreted from the thermophilic actinomycetes, Thermobifida fusca BCRC 19214. After cultivating for $48 \mathrm{~h}$, the culture broth accumulated $43.66 \mathrm{U} / \mathrm{mL}$ of peroxidase activity. The treatment of four types of lignocellulolytic byproducts, i.e., bagasse, corncob, pin sawdust, and Zizania latifolia Turcz husk, with Tfu-1649 alone increased the total phenolic compounds, with limited reducing sugars, but treatment with xylanase, Tfu-11, and peroxidase Tfu-1649 showed synergistic effects. Hence, the co-operative degradation of lignocelluloses by both peroxidase and xylanase could contribute to biomass decomposition and further applications in the agricultural and environmental industries.
\end{abstract}

Keywords: Lignocellulose; Peroxidase; Xylanase; Thermophilic actinomycetes; Thermobifida fusca

Contact information: a: Department of Cosmetic Science, Providence University, Taichung, 43301

Taiwan; b: Cosmetic Industry Research \& Development Center, Providence University, 43301 Taiwan;

c: Xtremes Pure Company, Taipei, 10652 Taiwan; *Corresponding author: chyang@pu.edu.tw

\section{INTRODUCTION}

Lignocellulose is a major part of plant biomass, which includes three major constituents, cellulose, hemicellulose, and lignins. Cellulose is the primary component of the lignocellulose cell wall and is a natural linear polysaccharide that is comprised of Dglucose units with $\beta-1,4$ glycosidic bonds (Kim et al. 2019). Hemicelluloses are another group of polysaccharides in lignocelluloses that are composed of xylans, mannans, xyloglucans, glucomannans, and $\beta$-glucans (Scheller and Ulvskov 2010). Lignins are composed of p-coumaryl, coniferyl, and sinapyl alcohol units via various inter-linkages of $\beta-\mathrm{O}-4, \beta-5$, and $\beta-\beta$ (Gonzalo et al. 2010; Vanholme et al. 2010) and is involved in hemicellulose (xylan) cross-linking and xylan linkage to other polysaccharides. Lignins provide strength and rigidity to plants and is resilient to degradation.

To complete the hydrolysis of lignocelluloses, a complex enzymatic system is required. Some enzymes hydrolyze the internal glycosidic bonds at random internal positions (endo-acting enzymes), while others cleave terminal linkages from non-reducing ends (exo-acting enzymes) (Andlar et al. 2018). Cellulose can be degraded by cellulase, which cleaves the $\beta$-1,4-glycosidic linkages of glucose units in the cellulose and consist of three main classes: endo- $\beta$-1-4-glucanase (EC 3.2.1.4), exoglucanases (EC 3.2.1.91), and exo- $\beta$-1,4-glucosidase (EC 3.2.1.21). Hemicellulose hydrolysis demands the co-operative action of endo- $\beta$-1-4-xylanase (EC 3.2.1.8), exo- $\beta$-1,4-xylosidase (EC 3.2.1.37), endo- $\beta$ 1-4-mannanase (EC 3.2.1.78), and exo- $\beta-1,4-$ mannosidase (EC 3.2.1.25). Peroxidases (EC 
1.11.1.7), laccases (EC 1.10.3.2), lignin peroxidases (LiP; EC 1.11.1.14), dye-decolorizing peroxidase (DyP; EC 1,11.1.19) (Catucci et al., 2020), and manganese-dependent peroxidases (MnP; EC 1.11.1.3) have been reported as the primary groups of lignin degrading enzymes (Woolridge 2014; Janusz et al. 2017; Andlar et al. 2018). Acetylxylan esterase (EC 3.1.1.72), feruloyl esterase (EC 3.1.1.73), p-coumaroyl esterase (EC 3.1.1.B10), $\alpha$-1-arabinofuranosidase (EC 3.2.1.55), xylan $\alpha$-1,2-glucuronosidase (EC 3.2.1.131), and $\alpha$-glucuronidase (EC 3.2.1.139) all increase the efficiency of lignocellulose degradation (Vries et al. 2000; Andlar et al. 2018). As previously reported, there are synergistic actions between an endoxylanase and a laccase against the natural lignocellulosic substrate (Fonseca-Maldonado et al. 2014).

Lignocellulose-degrading enzymes are produced by a variety of fungal and bacterial genera, in which most enzymes have been found in mesophilic microorganisms. Thermophilic microorganisms are considered to be a good source of novel and thermostable enzymes with potential industrial applications. The thermophilic actinomycete, Thermobifida fusca, was reported to be able to produce abundant extracellular lignocellulose-degrading enzymes (Chen et al. 2013a, 2016). However, the interaction between xylanase and peroxidase is not fully understood, especially with regards to lignocellulose products, e.g., bagasse, corncob, pin sawdust, and Zizania latifolia Turcz husk, which are common agricultural and environmental lignocellulose byproducts in Taiwan. Hence, in this study, the authors attempted to purify and examine the properties of the extracellular peroxidase secreted by $T$. fusca. The co-operative degradation of lignocellulose via peroxidase and xylanase was also evaluated.

\section{EXPERIMENTAL}

\section{Microorganisms}

Thermobifida fusca BCRC 19214 was isolated and routinely maintained in the author's laboratory (Chen et al. 2013b) and was stored in the Bioresource Collection and Research Center (Taiwan).

\section{Materials}

The Czapek-Dox powder, yeast extract, peptone, and agar were purchased from BD (Sparks, MD). The diethylaminoethyl cellulose (DEAE)-Sepharose CL-6B and Sephacyl S-200 columns were purchased from GE Healthcare (Little Chalfont, UK), while the sodium dodecyl sulfate-polyacrylamide gel electrophoresis (SDS-PAGE), acrylamide, buffer, reagents, molecular weight standards, and protein assay kit were purchased from Bio-Rad Laboratories (Hercules, CA). All other chemicals were obtained from SigmaAldrich (St. Louis, MO, USA), while the xylanase-Tfu11 was obtained from the E. coli transformant pXYL11 from the author's laboratory (Huang et al. 2010).

\section{Lignocellulose Sample Preparation}

The bagasse, corncobs, pin sawdust and Zizania latifolia Turcz husk samples were collected from a local market, which were thoroughly washed with tap water to remove dust, and then air-dried. The dried samples were chopped and milled to a 100-mesh size using an ultrafine pulverizer (MacroGreat, Yunlin, Taiwan) and stored at room temperature. 


\section{Cultivation and Purification of the Enzyme}

Thermobifida fusca BCRC 19214 was cultivated in a $500 \mathrm{~mL}$ Hinton flask containing $100 \mathrm{~mL}$ of an enzyme-producing medium consisting of $10.0 \mathrm{~g}$ of bagasse, $0.5 \mathrm{~g}$ of yeast extract, $4.0 \mathrm{~g}$ of $\mathrm{NH}_{4} \mathrm{NO}_{3}$, and $6.8 \mathrm{~g}$ of $\mathrm{KH}_{2} \mathrm{PO}_{4} \mathrm{~L}^{-1}$ of distilled water (with a $\mathrm{pH}$ of 9.0). The culture was inoculated at $50{ }^{\circ} \mathrm{C}$ and shaken (at $150 \mathrm{rpm}$ ) for $96 \mathrm{~h}$. The culture broth was centrifuged at $10000 \times$ gravity for $30 \mathrm{~min}$ to remove the cellular pellet, and the supernatant was used as the crude enzyme solution. Purification was performed using a 30 kDa Pellicon XL ultrafiltration system (Merck KGaA, Billerica, MA) as well as a DEAESepharose CL-6B and Sephacryl S-200 chromatography columns. The steps were performed according to the instructions provided by the manufacturer (Chen et al. 2013b).

\section{Enzyme Activity}

The peroxidase activity was determined by monitoring $455 \mathrm{~nm}$ in the reaction mixture containing $200 \mu \mathrm{L}$ of the enzyme, $20 \mu \mathrm{L}$ of catechol $(0.5 \mathrm{M}), 20 \mu \mathrm{L}$ of hydrogen peroxide $(50 \mathrm{mM}$ ), and $760 \mu \mathrm{L}$ of $50 \mathrm{mM}$ Tris- $\mathrm{HCl}$ buffer (with a $\mathrm{pH}$ of 8.8) (Doğan et al. 2007). The enzymatic assay was performed at $50{ }^{\circ} \mathrm{C}$. The blanks contained all compounds except for the enzyme solution, and one unit of peroxidase activity was defined as the amount of enzyme required to oxide $1 \mu \mathrm{mol}$ of the substrate $(1 \mathrm{mM})$ in 1 min under assay conditions. The xylanase activity was determined by measuring the release of reducing sugars from oat-spelt xylan (Huang et al. 2000). One unit of xylanase activity was defined as the amount of enzyme that released $1 \mu \mathrm{mol}$ of D-xylose $(1 \mathrm{mM})$ per min at $50{ }^{\circ} \mathrm{C}$.

\section{Analysis Methods}

The total phenolics of the lignocellulolytic hydrolysate was determined using a modified Folin-Ciocalteu method, using gallic acid as the standard (Kujala et al. 2000). The reducing sugars liberated via the hydrolysis of lignocellulose substrates in the mixture was determined using the dinitrosalicylic acid (DNS) method, where D-glucose was used to construct a standard curve.

\section{Statistical Analysis}

The data were analyzed in triplicates (or higher), which was expressed as the mean \pm standard error and compared to the appropriate control using the Student's $t$-test. A $p$ value of less than 0.05 indicated statistically significant differences.

\section{RESULTS AND DISCUSSION}

\section{Cultivation and Purification of T. fusca BCRC 19214 Peroxidase}

Thermobifida fusca BCRC 19214 was cultured as described in the Experimental section for $48 \mathrm{~h}$. A total of $43.66 \mathrm{U} / \mathrm{mL}$ peroxidase activities had accumulated in the culture broth. The results of the DEAE-Sepharose CL-6B ion-exchange as well as the Sephacyl S200 gel-filtration chromatography are shown in Fig. 1, while the results of the total purification process are summarized in Table 1. The obtained purified peroxidase exhibited $2.91 \%$ of the total initial activity with a 15.12-fold increase in specific activities when compared to the culture filtrate solution. The purified peroxidase was named Tfu-1649. 


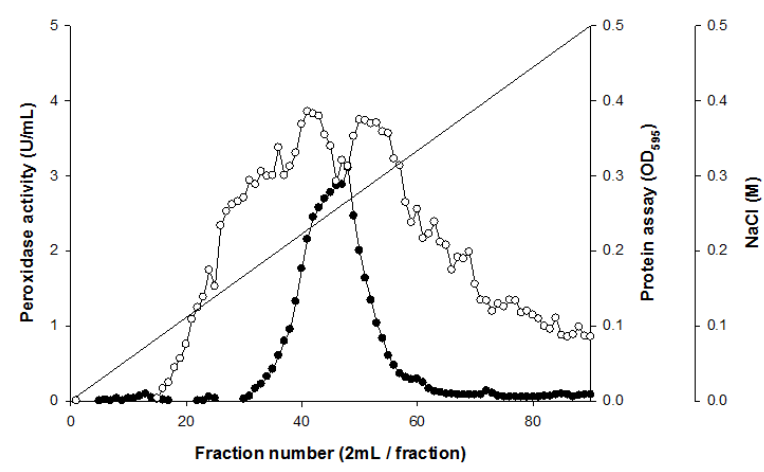

(a)

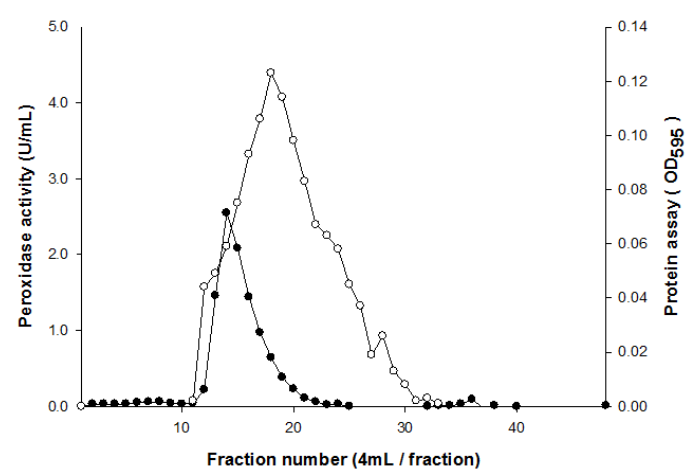

(b)

Fig. 1. Column chromatography of peroxidase Tfu-1649 purified from Thermobifida fusca BCRC19214. (a) diethylaminoethyl cellulose (DEAE)-Sepharose CL-6B column chromatography as well as (b) Sephacryl S-200 column chromatography. Symbol: (@) peroxidase activity, ( $(0)$ protein assay, $(-) \mathrm{NaCl}$

Table 1. Summarization of the Purification of Peroxidase Tfu-1649

\begin{tabular}{|c|c|c|c|c|c|}
\hline $\begin{array}{c}\text { Purification } \\
\text { step }\end{array}$ & $\begin{array}{c}\text { Total Protein } \\
(\mathrm{mg})\end{array}$ & $\begin{array}{c}\text { Total Activity } \\
(\mathrm{U})\end{array}$ & $\begin{array}{c}\text { Specific Activity } \\
(\mathrm{U} / \mathrm{mg})\end{array}$ & $\begin{array}{c}\text { Purification } \\
(\text { fold })\end{array}$ & $\begin{array}{c}\text { Yield } \\
(\%)\end{array}$ \\
\hline $\begin{array}{c}\text { Crude } \\
\text { supernatant }\end{array}$ & 31.14 & 43.66 & 1.40 & 1 & 100 \\
\hline Ultrafiltration & 9.35 & 5.95 & 0.64 & 0.45 & 13.63 \\
\hline $\begin{array}{c}\text { DEAE-Sepharose } \\
\text { CL-6B }\end{array}$ & 1.35 & 4.35 & 3.22 & 2.3 & 9.96 \\
\hline $\begin{array}{c}\text { Sephacryl S- } \\
200\end{array}$ & 0.06 & 1.27 & 21.17 & 15.12 & 2.91 \\
\hline
\end{tabular}

In addition, $T$. fusca is able to produce multiple types of peroxidases. Ball and Trigo (1995) used anion exchange chromatography to purify the T. fusca peroxidase, where two extracellular peroxidases were measured on non-denaturing gel electrophoresis. Their isoelectric points were 8.8 and 3.6, respectively. The molecular weight of the acidic peroxidase was $40 \mathrm{kDa}$. Moreover, a newly purified dye decolorizing peroxidase (DyP) was also found in $T$. fusca using a genome-mining approach with a molecular weight of 46 $\mathrm{kDa}$ (van Bloois et al. 2010); these peroxidases are all different from peroxidase Tfu-1649. Hence, to the best of the authors' knowledge, this was the first instance of identifying and purifying peroxidase Tfu-1649 from a culture broth of $T$. fusca.

\section{Properties of the T. fusca BCRC 19214 peroxidase}

As shown in Fig. 2, the purified peroxidase Tfu-1649 sample displayed a single protein band on the $10 \%$ SDS-PAGE, which was estimated to be approximately $60 \mathrm{kDa}$ based on its mobility compared to the standard proteins on the SDS-PAGE.

The optimum $\mathrm{pH}$ and temperature of the purified peroxidase Tfu-1649 sample were 9.0 and $60{ }^{\circ} \mathrm{C}$, respectively. Approximately $80 \%$ of the original activity still remained at $60{ }^{\circ} \mathrm{C}$ after $4 \mathrm{~h}$ (Fig. 3). The optimum temperature of the peroxidase, Tfu- 1649 was similar to other peroxidases found in actinomycetes (Table 2). The range of optimum temperatures 
for Streptomyces spp. peroxidase is between $30{ }^{\circ} \mathrm{C}$ to $80{ }^{\circ} \mathrm{C}$, with the strain AD001 showing the lowest optimum temperature. In addition, the optimum $\mathrm{pH}$ of peroxidase Tfu-1649 was 9.0, while in the case of the Streptomyces spp. peroxidase, it was lower than 8.5 (Rekik et al. 2015).

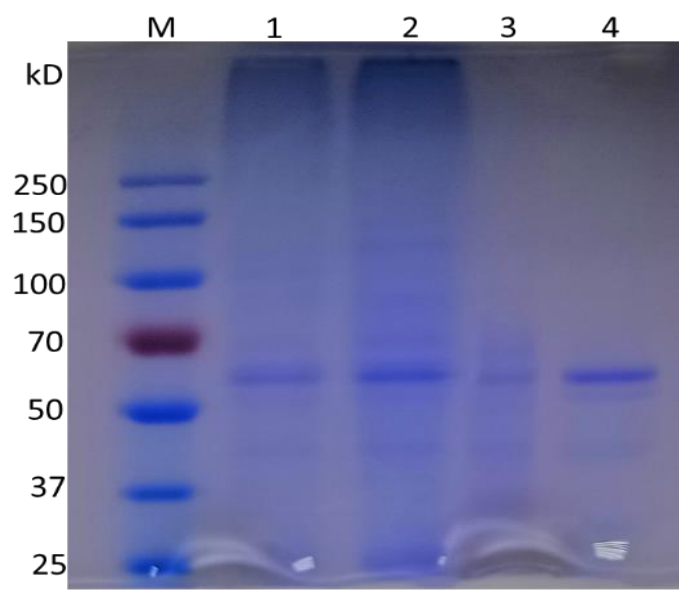

Fig. 2. Sodium dodecyl sulfate-polyacrylamide gel electrophoresis (SDS-PAGE) of peroxidase Tfu-1649 from Thermobifida fusca BCRC19214. Lane M: molecular weight marker; Lane 1: culture filtrate; Lane 2: Tfu-1649 purified from concentration; Lane 3: Tfu-1649 purified via diethylaminoethyl cellulose (DEAE)-Sepharose CL-6B chromatography; and Lane 4: Tfu-1649 purified via Sephacyl S-200 chromatography.

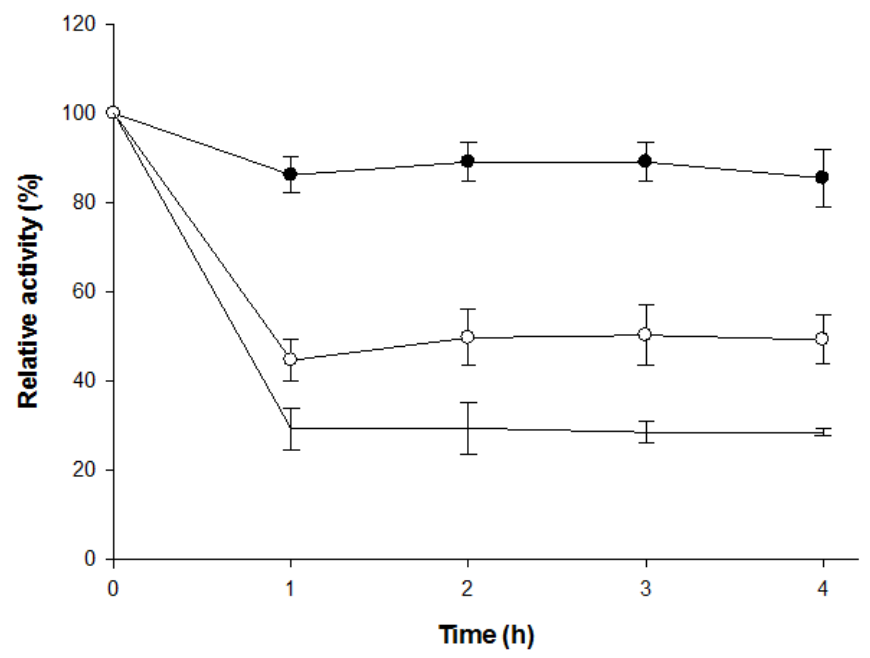

Fig. 3. Thermal stability of peroxidase Tfu-1649 purified from Thermobifida fusca BCRC19214, which was incubated at various temperatures for $1 \mathrm{~h}$ to $4 \mathrm{~h}$, after which the residual enzyme activity was determined. Symbol: $(\bullet) 60^{\circ} \mathrm{C},(\circ) 70^{\circ} \mathrm{C},(-) 80^{\circ} \mathrm{C}$ 
Table 2. Biochemical Properties of the Selected Purified Peroxidases

\begin{tabular}{|c|c|c|c|c|}
\hline $\begin{array}{l}\text { Strain } \\
\text { Enzyme }\end{array}$ & $\begin{array}{c}\text { Optimal } \\
\text { Temperature } \\
\left({ }^{\circ} \mathrm{C}\right)\end{array}$ & $\begin{array}{l}\text { Optimal } \\
\mathrm{pH}\end{array}$ & $\begin{array}{c}\text { Metal Ion (Relative activity \%) } \\
\text { Inhibitor }\end{array}$ & Source \\
\hline $\begin{array}{l}\text { Streptomyces sp. } \\
\text { AD001 }\end{array}$ & 30 & 7.5 & $\begin{array}{c}\mathrm{Hg}^{2+}(0 \%), \mathrm{Mg}^{2+}(56.5 \%), \mathrm{Zn}^{2+} \\
(47 \%), \mathrm{Cu}^{2+}(32 \%), \\
\mathrm{Co}^{2+}(27 \%)(1 \mathrm{mM}) \\
\mathrm{NaN}_{3}(11 \%), \text { EDTA }(36 \%)\end{array}$ & $\begin{array}{l}\text { Jeon et al. } \\
\quad 2002\end{array}$ \\
\hline $\begin{array}{l}\text { Streptomyces sp. } \\
\text { strain AH4 }\end{array}$ & 80 & 5 & $\begin{array}{c}\mathrm{Mn}^{2+}(225 \%), \mathrm{Mg}^{2+}(90 \%), \mathrm{Ca}^{2+} \\
(145 \%), \\
\mathrm{Cu}^{2+}(111 \%), \mathrm{Zn}^{2+}(25 \%), \mathrm{Co}^{2+} \\
(85 \%), \mathrm{Ag}^{2+}(56 \%), \mathrm{Hg}^{2+} \\
(10 \%), \mathrm{K}^{+}(165 \%)(5 \mathrm{mM}) \\
\mathrm{NaN}_{3}(40 \%), \text { Acetonitrile, } \\
\mathrm{DMSO}(20 \%), \text { Isopropyl } \\
\text { alcohol, ethanol, methanol } \\
\text { (increased } 125 \%)\end{array}$ & $\begin{array}{l}\text { Fodil et al. } \\
\quad 2012\end{array}$ \\
\hline $\begin{array}{l}\text { Streptomyces } \\
\text { albidoflavus TN644 }\end{array}$ & 75 & 4 & $\begin{array}{c}\mathrm{Mn}^{2+}(290 \%), \mathrm{Mg}^{2+}(180 \%) \\
\mathrm{Ca}^{2+}(112 \%), \\
\mathrm{Cu}^{2+}(108 \%), \mathrm{Zn}^{2+}(75 \%), \mathrm{Co}^{2+} \\
(65 \%), \mathrm{Ag}^{2+}(51 \%), \mathrm{Hg}^{2+}(6 \%) \\
\mathrm{K}^{+}(145 \%)(5 \mathrm{mM}), \mathrm{NaN}_{3}(5 \%) \\
\end{array}$ & $\begin{array}{l}\text { Jaouadi et } \\
\text { al. } 2014\end{array}$ \\
\hline $\begin{array}{l}\text { Streptomyces sp. } \\
\text { strain AM2 HaP1 }\end{array}$ & 55 & 6 & - & $\begin{array}{l}\text { Fodil et al. } \\
2011\end{array}$ \\
\hline $\begin{array}{l}\text { Streptomyces sp. } \\
\text { strain AM2 HaP2 }\end{array}$ & 55 & 7.5 & - & $\begin{array}{l}\text { Fodil et al. } \\
2011\end{array}$ \\
\hline $\begin{array}{c}\text { Streptomyces } \\
\text { griseosporeus SN9 }\end{array}$ & 60 & 8.5 & $1 \% \operatorname{SDS}(72 \%)$ & $\begin{array}{c}\text { Rekik et al. } \\
2015\end{array}$ \\
\hline $\begin{array}{l}\text { Rhodococcus sp. } \\
\text { T1 }\end{array}$ & 35 & 4 & $\begin{array}{c}\mathrm{Mg}^{2+}(100 \%), \mathrm{Ca}^{2+}(70 \%), \mathrm{Mn}^{2+} \\
(40 \%), \mathrm{Zn}^{2+}(40 \%), \\
\mathrm{Cu}^{2+}(60 \%), \mathrm{Co}^{2+}(60 \%), \mathrm{K}^{+}(55 \\
\%)(1 \mathrm{mM}) \\
\beta-\mathrm{Me}(30 \%), \text { EDTA (95\%) }\end{array}$ & $\begin{array}{l}\text { Sahinkaya et } \\
\text { al. } 2019\end{array}$ \\
\hline $\begin{array}{c}\text { Thermobifida fusca } \\
\text { DyP-type } \\
\text { peroxidase }\end{array}$ & 45 to 60 & $\begin{array}{l}5.0 \text { to } \\
5.5\end{array}$ & & $\begin{array}{l}\text { Rahmanpour } \\
\text { et al. } 2016\end{array}$ \\
\hline $\begin{array}{l}\text { Thermomonospora } \\
\text { fusca BD25 }\end{array}$ & 60 & $\begin{array}{l}7.0 \text { to } \\
8.0\end{array}$ & - & $\begin{array}{l}\text { Ball and } \\
\text { Trigo } 1995\end{array}$ \\
\hline $\begin{array}{c}\text { Thermobifida fusca } \\
\text { BCRC } 19214 \\
\text { Tfu-1649 }\end{array}$ & 60 & 9.0 & $\begin{array}{c}\mathrm{Na}^{+}(99 \%), \mathrm{K}^{+}(105 \%), \\
\mathrm{Ca}^{2+}(107 \%), \mathrm{Mg}^{2+}(91 \%), \\
\mathrm{Zn}^{+}(88 \%), \mathrm{Cu}^{2+}(7 \%), \\
\mathrm{Mn}^{2+}(17 \%), \mathrm{Co}^{2+}(0 \%), \\
\mathrm{Hg}^{+}(31 \%), \mathrm{Ni}^{+}(1 \%) .(1 \mathrm{mM}) \\
\mathrm{SDS}(90 \%), \mathrm{NaN}_{3}(0 \%), \beta-\mathrm{ME} \\
(0 \%), \mathrm{PMSF}(41 \%)(10 \mathrm{mM})\end{array}$ & $\begin{array}{l}\text { Measured in } \\
\text { this study }\end{array}$ \\
\hline $\begin{array}{l}\text { Pseudomonas } \\
\text { aeruginosa } \\
\text { PKE117 }\end{array}$ & - & 3.5 & $\begin{array}{c}\mathrm{Cu}^{2+}(106 \%), \mathrm{Zn}^{2+}(103 \%), \mathrm{Ag}^{2+} \\
(92 \%), \mathrm{Co}^{2+}(92 \%), \mathrm{Mn}^{2+}(98 \%) \\
\mathrm{Ca}^{2+}(97 \%), \mathrm{Mg}^{2+}(92 \%)(1 \mathrm{mM}) \\
\text { SDS }(91 \%), \operatorname{EDTA}(100 \%)\end{array}$ & Li et al. 2012 \\
\hline
\end{tabular}

According to the metal ions and the chemical reagents tested, it was found that the activity of purified peroxidase Tfu- 1649 was strongly inhibited by $1 \mathrm{mM}$ of $\mathrm{Cu}^{2+}, \mathrm{Mn}^{2+}$, $\mathrm{Co}^{2+}, \mathrm{Hg}^{+}$, and $\mathrm{Ni}^{+}$and only partially inhibited by $1 \mathrm{mM}$ of $\mathrm{Zn}^{2+}$. The $1 \mathrm{mM} \mathrm{NaN}, \beta-$ 
mercaptoethanol, and $10 \mathrm{mM}$ phenyl-methyl-sulfonyl fluoride (PMSF) strongly inhibited the enzymatic activity of peroxidase Tfu-1649 (as shown in Fig. 4). The effects of the organic solvents on the activity of purified peroxidase Tfu-1649 are shown in Fig. 5. With $10 \%$ water miscible solvents, e.g., acetonitrile, dimethyl sulfoxide (DMSO), isopropanol, and acetone, in the reaction system, the enzymatic activity increased by $115 \%$ to $135 \%$, while the enzymatic activity of peroxidase Tfu-1649 was inhibited by $20 \%$ methanol and $10 \%$ ethanol. Isopropanol in the incubation mixture may produce a great increase of the enzyme activity. In the previous reports, it also increased the activities of starch synthetase, and thrombin (Judewicz et al. 1972; Shvachko and Kibirev 1988).

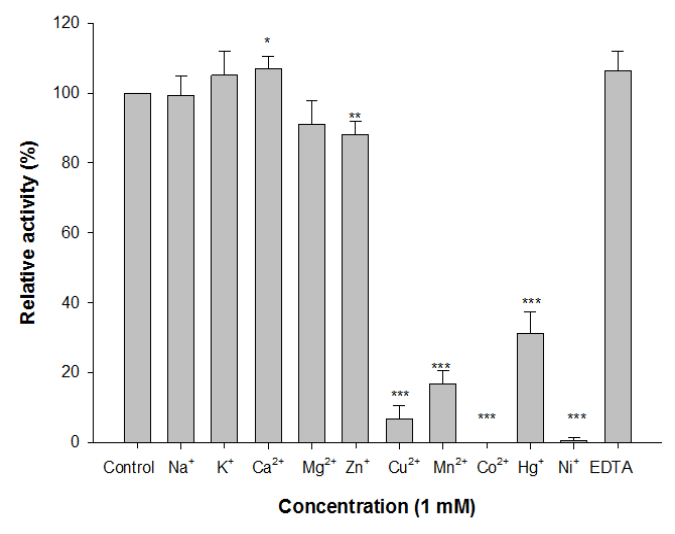

(a)

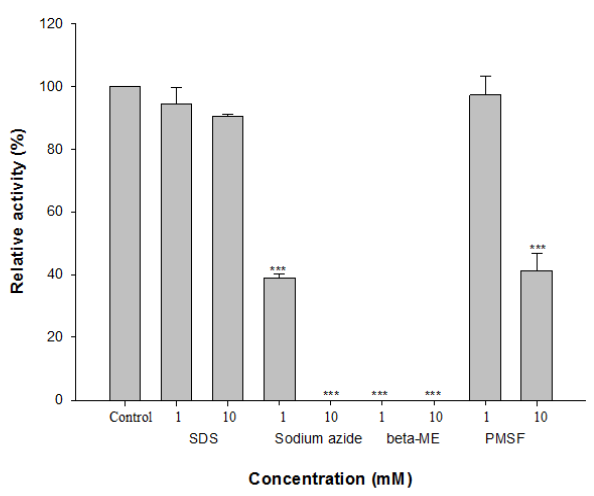

(b)

Fig. 4. Effect of various (a) ions and (b) chemical reagents on peroxidase Tfu-1649 purified from Thermobifida fusca BCRC19214, including ethylenediaminetetraacetic acid (EDTA), sodium lauryl sulfate (SDS), $\beta$-mercaptoethanol (beta-ME), and phenyl-methyl-sulfonyl fluoride (PMSF)

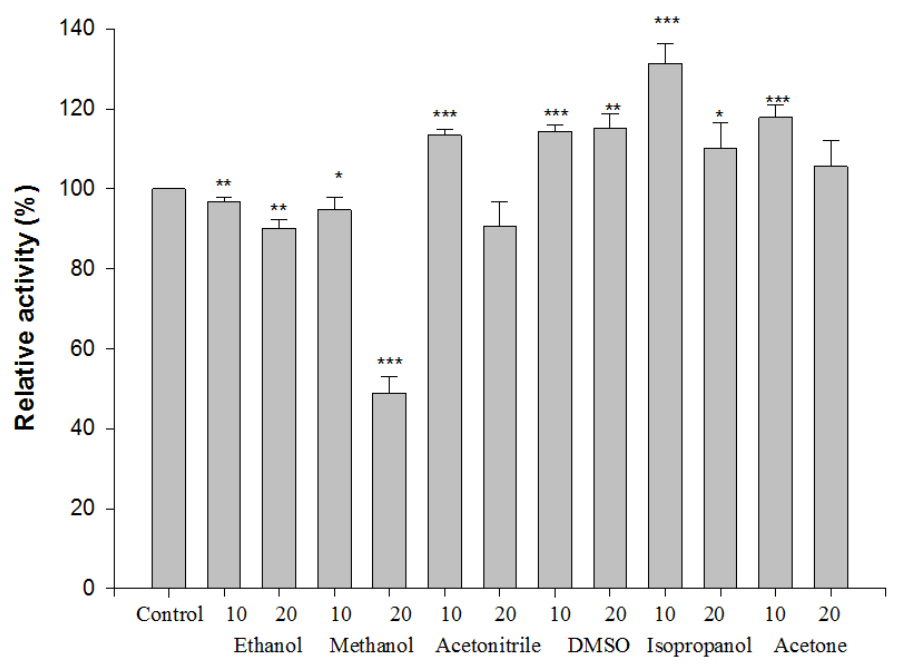

Concentration (\%)

Fig. 5. Effect of various organic solvents, including dimethyl sulfoxide (DMSO), on peroxidase Tfu-1649 purified from Thermobifida fusca BCRC19214

Peroxidase Tfu-1649 was strongly inhibited by $1 \mathrm{mM}$ of $\mathrm{Cu}^{2+}, \mathrm{Mn}^{2+}, \mathrm{Co}^{2+}, \mathrm{Hg}^{+}$, and $\mathrm{Ni}^{+}$. In addition, $\mathrm{Cu}^{2+}$ also inhibited Streptomyces sp. AD001 (Jeon et al. 2002) and Rhodococcus sp. T1 (Sahinkaya et al. 2019) peroxidase, but it acted as an activator for $S$. 
albidoflavus TN644 (Jaouadi et al. 2014) and P. aeruginosa PKE117 (Li et al. 2012). The peroxidase activity of Rhodococcus sp. T1 was inhibited by $\mathrm{Mn}^{2+}$ (Sahinkaya et al. 2019), but $\mathrm{Mn}^{2+}$ activated the enzymatic activities of $S$. sp. AH4 (Fodil et al. 2012) and $S$. albidoflavus TN644 (Jaouadi et al. 2014). Moreover, the inhibitory effects of $\mathrm{Co}^{2+}$ and $\mathrm{Hg}^{+}$ on peroxidase Tfu-1649 were similar to the other peroxidases summarized in Table 2. In addition, the inhibitory effect of $\mathrm{Ni}^{+}$on peroxidases was first demonstrated in the author's studies, to the best of the author's knowledge. Furthermore, the enzymatic activity of peroxidase Tfu- 1649 was also inhibited by $\mathrm{NaN}_{3}$, which was similar to the strains AD001 (Jeon et al. 2002), AH4 (Fodil et al. 2012), and TN644 (Jaouadi et al. 2014). Phenylmethylsulfonyl fluoride (PMSF) is a serine protease inhibitor, while $\beta$ mercaptoethanol is used to reduce disulfide bonds. Thus, the fact that peroxidase Tfu-1649 was inhibited by PMSF and $\beta$-mercaptoethanol revealed that serine and cysteine may act as important amino acids in the active center of the enzyme.

\section{Enzymatic Activity on Lignin Model Compounds}

The enzyme activities on five compounds were tested in this experiment. As shown in Fig. 6, purified peroxidase Tfu-1649 exhibited high activities for catechol and L-DOPA, while 2,6-DMP, 2,4-DCP, and guaiacol were not good candidates for the oxidation reaction. Different enzymes have different substrate specificities. The fungal peroxidase (Pspd) found in Perenniporia subacida had different substrate specificities; it had the highest peroxidase activity against n-propanol, while 2,6-DMP, guaiacol, and catechol had relative activities of $82.14 \%, 79.34 \%$, and $74.34 \%$, respectively (Si and Cui 2013).

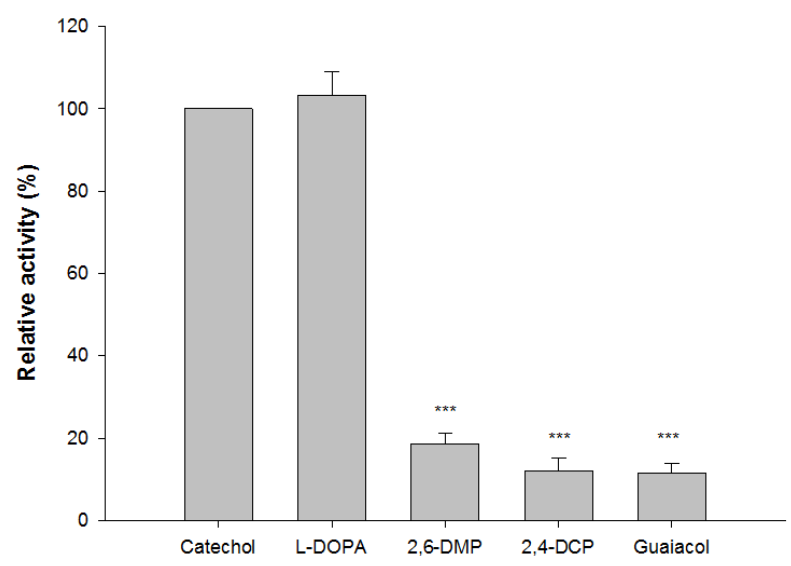

Fig. 6. Effect of the enzyme activities on five compounds on peroxidase Tfu-1649 purified from Thermobifida fusca BCRC19214

\section{Co-operative Enzymatic Degradation of Lignocellulose}

In this study, the authors investigated the synergistic effects of xylanase and peroxidase in terms of lignocellulose degradation. Four lignocellulose substrates were treated with only xylanase to produce the reducing sugars in the reaction solution (as shown in Fig. 7a), while total phenolic compounds accumulated in the reaction solution across all four tests (as shown in Fig. 7b). When the substrates were treated with only peroxidase Tfu-1649, the total phenolic compounds all accumulated in the culture broth, with a limited amount of reducing sugars produced by the peroxidase. However, when the substrates were treated with both xylanase Tfu-11 and peroxidase Tfu-1649, synergistic effects were observed. In addition, corncob was the best candidate for degradation via xylanase Tfu-11 
and peroxidase Tfu-1649. After incubating xylanase Tfu-11 and peroxidase Tfu-1649 for $24 \mathrm{~h}, 760 \mu \mathrm{g} / \mathrm{ml}$ reducing sugars were accumulated in the reaction solution. However, after incubation with xylanase Tfu-11 or peroxidase Tfu-1649 alone for $24 \mathrm{~h}$, only $380 \mu \mathrm{g} / \mathrm{mL}$ or $30 \mu \mathrm{g} / \mathrm{mL}$ reducing sugar was accumulated in the reaction solution. Furthermore, 336 $\mu \mathrm{g} / \mathrm{mL}$ of total phenolic compounds were released from the lignocelluloses and accumulated in the reaction solution after incubation with xylanase Tfu-11 and peroxidase Tfu-1649 for $24 \mathrm{~h}$. There were only $190 \mu \mathrm{g} / \mathrm{mL}$ or $180 \mu \mathrm{g} / \mathrm{mL}$ of total phenolic compounds accumulated in the reaction solution after incubated $24 \mathrm{~h}$ with xylanase Tfu-11 or peroxidase Tfu-1649, respectively. Hence, xylanase Tfu-11 and peroxidase Tfu-1649 displayed significant synergistic effects when applied to corncob degradation, and these effects were also observed in the bagasse and sawdust reactions. However, the synergistic effect of xylanase Tfu-11 and peroxidase Tfu-1649 on Zizania latifolia Turcz husk was different relative to the other three substrates. The xylanase Tfu-11 hydrolyzed the Zizania latifolia Turcz husk and the reducing sugars accumulated in the broth, but the co-operation effect with peroxidase Tfu-1649 did not cause a synergistic increase in terms of the accumulated reducing sugars.

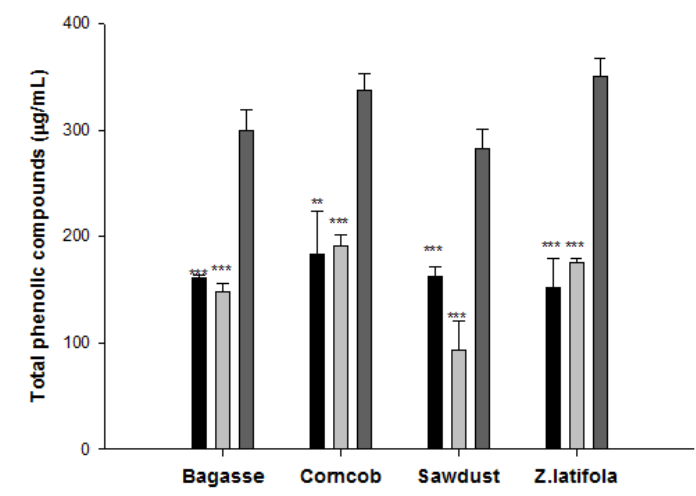

(a)

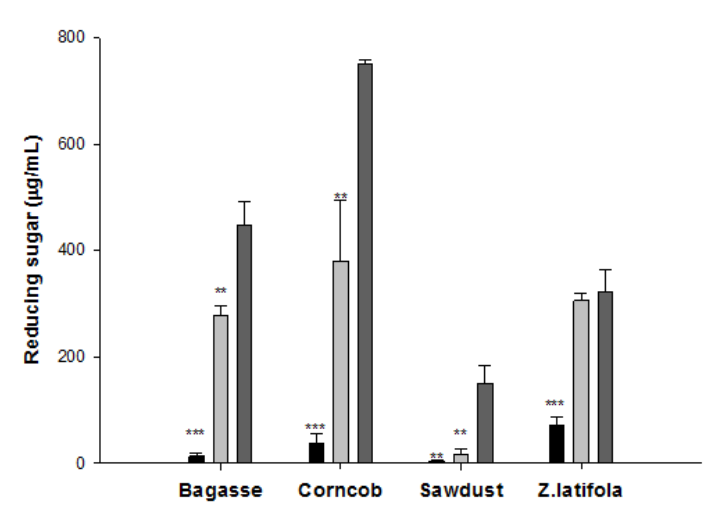

(b)

Fig. 7. Effects of peroxidase Tfu-1649 and xylanase Tfu-11 on the lignocellulolytic by-products concentrations of the (a) total phenolic compounds and (b) the reducing sugar. peroxidase, Tfu-1649; $\square$ : xylanase, Tfu-11; $\square$ : peroxidase, Tfu-1649 and xylanase, Tfu-11. Data was reported as the mean \pm standard error in triplicate (Student's $t$-test $p$ values: ${ }^{*}=p$-value less than $0.05 ;{ }^{* *}=p$-value less than 0.01 ; and ${ }^{* * *}=p$-value less than 0.001 )

\section{CONCLUSIONS}

1. Thermobifida fusca BCRC 19214 had a peroxidase activity of $43.66 \mathrm{U} / \mathrm{mL}$ when subjected to a bagasse substrate.

2. Synergistic effects were observed when the substrates were treated with both xylanase Tfu-11 and peroxidase Tfu-1649.

3. The results prove that the lignocellulose lignin barrier was disrupted by peroxidase Tfu1649, thus rendering the lignocellulose structure more susceptible to degradation by xylanase Tfu-11. These findings may be helpful in granting a better understanding of the catalysis of lignocellulolytic substrates via complex hydrolytic enzyme systems. 


\section{ACKNOWLEDGMENTS}

The authors are grateful for the support of the Ministry of Science and Technology of the Republic of China (MOST 104-2313-B-126-001-MY3 and MOST 107-2313-B-126001-MY3).

\section{REFERENCES CITED}

Andlar, M., Rezić, T., Marđetko, N., Kracher, D., Ludwig, R., and Šantek, B. (2018). "Lignocellulose degradation: An overview of fungi and fungal enzymes involved in lignocellulose degradation," Engineering in Life Sciences 18(11), 768-778. DOI: 10.1002/elsc. 201800039

Ball, A. S., and Trigo, C. (1995). "Characterization of a novel non-haem-containing extracellular peroxidase from Thermomonospora fusca," Biochemical Society Transactions 23(2), 272-276. DOI: 10.1042/bst0230272

Catucci, G., Valetti, F., Sheila J. Sadeghi, S. J., and Gilardi, G. (2020). "Biochemical features of dye-decolorizing peroxidases: Current impact on lignin degradation," Biotechnology and Applied Biochemistry 67(5), 751-759. DOI: 10.1002/bab.2015

Chen, C.-Y., Hsieh, Z.-S., Cheepudom, J., Yang, C.-H., and Meng, M. (2013a). "A 24.7kDa copper-containing oxidase, secreted by Thermobifida fusca, significantly increasing the xylanase/cellulase-catalyzed hydrolysis of sugarcane bagasse," Applied Microbiology and Biotechnology 97(20), 8977-8986. DOI: 10.1007/s00253-0134727-y

Chen, C.-Y., Huang, Y.-C., Wei, C.-M., Meng, M., Liu, W.-H., and Yang, C.-H. (2013b). "Properties of the newly isolated extracellular thermo-alkali-stable laccase from thermophilic actinomycetes, Thermobifida fusca and its application in dye intermediates oxidation," AMB Express 3(49), 1-9. DOI: 10.1186/2191-0855-3-49

Chen, C.-Y., Lee, C.-C., Chen, H.-S., Yang, C.-H., Wang, S.-P., Wu, J.-H., and Meng, M. (2016). "Modification of lignin in sugarcane bagasse by a monocopper hydrogen peroxide-generating oxidase from Thermobifida fusca," Process Biochemistry 51(10), 1486-1495. DOI: 10.1016/j.procbio.2016.07.009

de Gonzalo, G., Colpa, D. I., Habib, M. H. M., and Fraaije, M. W. (2010). "Bacterial enzymes involved in lignin degradation," Journal of Biotechnology 236, 110-119. DOI: $10.1016 /$ j.jbiotec.2016.08.011

de Vries, R. P., Kester, H. C. M., Poulsen, C. H., Benen, J. A. E., and Visser, J. (2000). "Synergy between enzymes from Aspergillus involved in the degradation of plant cell wall polysaccharides," Carbohydrate Research 327(4), 401-410. DOI: 10.1016/s0008-6215(00)00066-5

Doğan, S., Turan, P., Doğan, M., Arslan, O., and Alkan, M. (2007). "Variations of peroxidase activity among Salvia species," Journal of Food Engineering 79(2), 375382. DOI: 10.1016/j.jfoodeng.2006.02.001

Fodil, D., Badis, A., Jaouadi, B., Zarâi, N., Ferradji, F. Z., and Boutoumi, H. (2011). "Purification and characterization of two extracellular peroxidases from Streptomyces sp. strain AM2, a decolorizing actinomycetes responsible for the biodegradation of natural humic acids," International Biodeterioration \& Biodegradation 65(3), 470478. DOI: 10.1016/j.ibiod.2011.01.009

Fodil, D., Jaouadi, B., Badis, A., Nadia, Z. J., Ferradji, F. Z., Bejar, S., and Boutoumi, H. (2012). "A thermostable humic acid peroxidase from Streptomyces sp. strain AH4: 
Purification and biochemical characterization," Bioresource Technology 111, 383390. DOI: 10.1016/j.biortech.2012.01.153

Fonseca-Maldonado, R., Ribeiro, L. F., Furtado, G. P., Arruda, L. M., Meleiro, L. P., Alponti, J. S., Botelho-Machado, C., Vieira, D. S., Bonneil, E., Furriel, R. P. M., Thibault, P., and Ward, R. J. (2014). "Synergistic action of co-expressed xylanase/laccase mixtures against milled sugar cane bagasse," Process Biochemistry 49(7), 1152-1161.

Huang, Y.-C., Chen, G.-H., Chen, Y.-F., Chen, W.-L., and Yang, C.-H. (2010). "Heterologous expression of thermostable acetylxylan esterase gene from Thermobifida fusca and its synergistic action with xylanase for the production of xylooligosaccharides," Biochemical and Biophysical Research Communications 400(4), 718-723. DOI: 10.1016/j.bbrc.2010.08.136

Janusz, G., Pawlik, A., Sulej, J., Swiderska-Burek, U., Jarosz-Wilkolazka, A., and Paszczynski, A. (2017). "Lignin degradation: Microgrganisms, enzymes involved, genomes analysis and evolution," FEMS Microbiology Reviews 41, 941-962.

Jaouadi, B., Rekik, H., Badis, A., Jaouadi, N. Z., Belhoul, M., Hmidi, M., Kourdali, S., Fodil, D., and Bejar, S. (2014). "Production, purification, and characterization of a highly thermostable and humic acid biodegrading peroxidase from a decolorizing Streptomyces albidoflavus strain TN644 isolated from a Tunisian off-shore oil field," International Biodeterioration \& Biodegradation 90, 36-44. DOI:

10.1016/j.ibiod.2014.02.001

Jeon, J.-H., Han, Y.-J., Kang, T.-G., Kim, E.-S., Hong, S.-K., and Jeong, B.-C. (2002). "Purification and characterization of 2,4-dichlorophenol oxidizing peroxidase from Streptomyces sp. AD001," Journal of Microbiology and Biotechnology 12(6), 972 978.

Judewicz, N. D., Lavintman, N., Cardini, C. E. (1972). "Effect of isopropanol on the activity of particulate starch synthetase," Phytochemistry 11(7), 2213-2215.

Kim, J.-Y., Lee, H. W., Lee, S. M., Jae, J., and Park, Y.-K. (2019). “Overview of the recent advances in lignocellulose liquefaction for producing biofuels, bio-based materials and chemicals," Bioresource Technology 279, 373-384. DOI: 10.1016/j.biortech.2019.01.055

Kujala, T. S., Loponen, J. M., Klika, K. D., and Pihlaja, K. (2000). "Phenolics and betacyanins in red beetroot (Beta vulgaris) root: Distribution and effect of cold storage on the content of total phenolics and three individual compounds," Journal of Agricultural Food Chemistry 48(11), 5338-5342. DOI: 10.1021/jf000523q

Li, J., Liu, C., Li, B., Yuan, H., Yang, J., and Zheng, B. (2012). "Identification and molecular characterization of a novel DyP-type peroxidase from Pseudomonas aeruginosa PKE117," Applied Biochemistry and Biotechnology 166(3), 774-785. DOI: $10.1007 / \mathrm{s} 12010-011-9466-\mathrm{X}$

Lončar, N., and Fraaije, M. W. (2015). "Not so monofunctional - a case of thermostable Thermobifida fusca catalase with peroxidase activity," Applied Microbiology and Biotechnology 99(5), 2225-2232. DOI: 10.1007/s00253-014-6060-5

Rahmanpour, R., Rea, D., Jamshidi, S., Fülöp, V., and Bugg, T. D. H. (2016). "Structure of Thermobifida fusca DyP-type peroxidase and activity towards kraft lignin and lignin model compounds," Archives of Biochemistry and Biophysics 594, 54-60. DOI: 10.1016/j.abb.2016.02.019

Rekik, H., Nadia, Z. J., Bejar, W., Kourdali, S., Belhoul, M., Hmidi, M., Benkiar, A., Badis, A., Sallem, N., Bejar, S. (2015). "Characterization of a purified decolorizing 
detergent-stable peroxidase from Streptomyces griseosporeus SN9," International Journal of Biological Macromolecules 73, 253-263. DOI:

10.1016/j.ijbiomac.2014.11.021

Sahinkaya, M., Colak, D. N., Ozer, A., Canakci, S., Deniz, I., and Belduz, A. O. (2019). "Cloning, characterization and paper pulp applications of a newly isolated DyP type peroxidase from Rhodococcus sp. T1," Molecular Biology Reports 46, 569-580. DOI: 10.1007/s11033-018-4509-9

Scheller, H. V., and Ulvskov, P. (2010). "Hemicelluloses," Annual Review of Plant Biology 61, 263-289. DOI: 10.1146/annurev-arplant-042809-112315

Shvachko, L. P., and Kibirev, V. K. (1988). "Effect of isopropanol on the enzymatic activity and stability of thrombin," Ukrainskii Biokhimicheskii Zhurnal 60(3), 15-19.

Si, J., and Cui, B.-K. (2013). "A new fungal peroxidase with alkaline-tolerant, chlorideenhancing activity and dye decolorization capacity," Journal of Molecular Catalysis B: Enzymatic 89, 6-14. DOI: 10.1016/j.molcatb.2012.12.002

van Bloois, E., Pazmiño, D. E. T., Winter, R. T., and Fraaije, M. W. (2010). "A robust and extracellular heme-containing peroxidase from Thermobifida fusca as prototype of a bacterial peroxidase superfamily," Applied Microbiology and Biotechnology 86(5), 1419-1430. DOI: 10.1007/s00253-009-2369-x

Vanholme, R., Demedts, B., Morreel, K., Ralph, J., and Boerjan, W. (2010). “Lignin biosynthesis and structure," Plant Physiology 153(3), 895-905. DOI: 10.1104/pp.110.155119

Woolridge, E. M. (2014). "Mixed enzyme systems for delignification of lignocellulosic biomass," Catalysts 4(1), 1-35. DOI: 10.3390/catal4010001

Article submitted: September 22, 2020; Peer review completed: December 5, 2020; Revised version received and accepted: December 10, 2020; Published: December 15, 2020.

DOI: $10.15376 /$ biores.16.1.942-953 